\title{
Hepatoprotective Effect of Citrus sinensis (L.) Osbeck Ethanol Extract in Paracetamol-Induced Rats
}

\author{
Maya Sari Mutia, Linda Chiuman \\ Master of Public Health University of Prima Indonesia, Medan, Indonesia
}

\begin{abstract}
Based on data from the National Poison Data System of the American Association of Poison Control Center, it is reported that there is a high number of death and liver transplantation due to paracetamol and other combination drugs of paracetamol toxicity. Citrus sinensis (L.) Osbeck (Sunkist) is a fruit that has been widely studied for its various therapeutic effects. This study aimed to explore the potential of Sunkist peels as a hepatoprotection agent against the toxicity of paracetamol. This was an experimental study conducted in May 2019 at the Pharmacy Biology Laboratory of Pharmacy Faculty, University of North Sumatera on 15 rats that were divided into 5 groups of treatment (negative, positive, and 300,450, and $600 \mathrm{mg} / \mathrm{kgBW}$ Sunkist ethanol extract) and received treatment for 14 days. The AST and ALT was assessed using the dyasis manual assay. Data were then analyzed using one-way ANOVA, followed by Post-hoc test. The results of this study showed that the ALT and AST levels were significantly different (P-value<0.05) between the negative (ALT: $438.73 \mathrm{U} / \mathrm{L}$; AST: $334.37 \mathrm{U} / \mathrm{L}$ ) group and the positive (ALT: 152.34 U/L; AST: $49.7 \mathrm{U} / \mathrm{L}$ ). Futhermore, these levels were also significantly different between the negative group and the group that received $600 \mathrm{mg} / \mathrm{kg}$ BW of Sunkist peel ethanol extract (ALT: $189.15 \mathrm{U} / \mathrm{L}$; AST: 69.25 U/L). Hence, Sunkist peels have a potential to provide hepatoprotection effects just like catechin rutin.
\end{abstract}

Key words: ALT, AST, Citrus sinensis L. Osbeck, ethanol, paracetamol, sunkist

\section{Efek Hepatoprotektif Ekstrak Etanol Citrus sinensis L. Osbeck pada Tikus yang Diinduksi Parasetamol}

\begin{abstract}
Abstrak
Berdasar data dari American Association of Poison Control Centers' National Poison Data System dilaporkan angka kematian dan transplantasi hati yang tinggi akibat toksisitas parasetamol atau dalam bentuk kombinasi. Citrus sinensis L. Osbeck (sunkist) sebagai produk alami secara luas diteliti untuk berbagai efek terapi. Penelitian ini bertujuan mengeksplorasi potensi kulit sunkist sebagai perlindungan terhadap efek toksik dari parasetamol. Penelitian ini merupakan penelitian eksperimental yang dilakukan pada Mei 2019 di Laboratorium Biologi Farmasi, Fakultas Farmasi, Universitas Sumatera Utara. Penelitian ini dilakukan terhadap 15 tikus yang dibagi menjadi 5 kelompok perlakuan (kontrol negatif, kontrol positif, ekstrak sunkist dengan dosis, 300, 450, dan $600 \mathrm{mg} / \mathrm{kgBB}$ ). Perlakuan yang didapat pada tiap-tiap kelompok dilakukan selama 14 hari. Uji AST dan ALT menggunakan prosedur dari dyasis. Analisis data menggunakan one way ANOVA dan diikuti Post-Hoc Test. Hasil penelitian ini menunjukkan bahwa kadar ALT dan AST memiliki perbedaan yang signifikan (nilai $p<0,05)$ antara kontrol negatif (ALT: 438.73 U/L; AST: 334.37 U/L) dengan kelompok kontrol positif (ALT: 152.34 U/L; AST: 49.7 U/L) dan kelompok tikus yang menerima ekstrak etanol kulit jeruk sunkist $600 \mathrm{mg} / \mathrm{kg}$ BB (ALT: 189.15 U/L; AST: $69.25 \mathrm{U} / \mathrm{L}$ ). Oleh karena itu, kulit sunkist memiliki efek hepatoproteksi potensial seperti katekin rutin.
\end{abstract}

Kata kunci: ALT, AST, Citrus sinensis L. Osbeck, etanol, parasetamol, sunkist

Corresponding Author: Maya Sari Mutia, Master of Public Health University of Prima Indonesia, Jalan Sekip Simpang Sei Kambing, Medan Petisah 20111, North Sumatera, Indonesia, Email: mayasarimutia11@gmail.com 


\section{Introduction}

Paracetamol, also known as acetaminophen, is a widely used over-the-counter drug in the world that is considered as a safe and effective analgesic and antipyretic drug. This drug was initially synthesized in 1878 by Harmon N Morse of John Hopkins University via the reduction of P-nitrophenol with Tin in glacial acetic acid. However, it was not used as a medication for the next 15 years after it was first discovered. In 1948, Paracetamol was sold for the first time by McNeil Laboratories for pain and fever relief in children under the brand name of Tylenol children. ${ }^{1-3}$

The normal dose of paracetamol as the antipyretic drug is $15 \mathrm{mg} / \mathrm{kgBW}$ every $6 \mathrm{~h}(\leq 60$ $\mathrm{mg} / \mathrm{kgBW} /$ day). Meanwhile, the recommended dosage as analgesics is $15 \mathrm{mg} / \mathrm{kgBW}$ every 4-6 hours (max dosage (60-90 mg/kgBW/day) peroral and $20 \mathrm{mg} / \mathrm{kgBW}$ every 6 hours, up to a maximum dose of $90 \mathrm{mg} / \mathrm{kgBW} /$ day. A dose of paracetamol of more than $90 \mathrm{mg} / \mathrm{kgBW} /$ day leads to a high risk of hepatotoxicity among sick children older than 2 years whereas a dose that is higher than $150 \mathrm{mg} / \mathrm{kgBW}$ is associated with liver toxicity. ${ }^{2}$

Paracetamol also has a potential incidence of toxicity. There were more than 28 billion paracetamol combination products dispensed in 2005. Furthermore, in 2009, the National Poison Data System of the American Association of Poison Control Center reported 401 deaths related to the use of paracetamol or paracetamol combination drugs. Recently, paracetamolinduced liver failure has been documented as the second most common cause of liver transplantation in the US. ${ }^{1,2}$

In recent years, herbal medicine becomes a favorite medicine due to the back-to-nature medicine movement. The Vice President for Professional Products Soho Global Health, Sugiharjo, stated that herbal medicine has been used in $80 \%$ of drug use all over the world. The Ministry of Health of the Republic of Indonesia has reported that, in 2006, the market for Herbal Medicine in Indonesia was around IDR 5 trillion, which then increased IDR 6 trillion in 2007, and up to IDR 13 trillion in 2012. ${ }^{4}$ Meanwhile, a report on e-commerce on health and beauty products from Gogobli showed that the market of herbal medicine is now competing with the market of the over the counter drugs. The trade market for herbal medicine in Indonesia reached 15 billion IDR in 2017. ${ }^{5}$

Citrus sinensis L. Osbeck as a natural product has been widely studied for various therapeutic effects. One of the studies reported that orange peels have a potential as hepatoprotector against cypermethrin, which was evident from the histopathological findings in cypermethrininduced rat liver that showed no noticeable histological alteration after 30 days of treatments. ${ }^{6}$ Hence, this study aimed to explore the protective effect of Sunkist against the liver of paracetamol-induced rats.

\section{Methods}

This was an experimental study conducted in May 2019 at the Pharmacy Biology Laboratory of the Faculty of Pharmacy, University of North Sumatera which has been approved by the Health Research Ethics Committee from Universitas Prima Indonesia (Registration No. 1271012S).

The materials used in this study were $96 \%$ ethanol, sunkist peels, AST/ALT dyasis reagent, carboxymethyl cellulose sodium (Na-CMC), aquadest, catechin rutin, paracetamol, EDTA, and rat feed.

The fresh Sunkist peels were obtained from one of the traditional markets in Pancur Batu subdistrict, North Sumatera, Indonesia, and had gone through selection and identification at the Medanense Herbarium of the Faculty of Mathematics and Natural Sciences, University of North Sumatera. The peels were dried and made into simplicia powder form. The simplicia powder was macerated by $96 \%$ ethanol for 5 days and then filtered. The residue was remacerated using the same method for 2 days. Filtrate was then collected and evaporated using a rotary evaporator.

The number of rats was determined by G*Power 3.0.10 which required a minimum of 10 rats. This study used a sample of 15 rats. ${ }^{7}$ These rats were acclimatized for 7 days preceding the treatment and were divided into 5 groups of treatment: negative control $(2 \mathrm{~mL}$ of carboxymethyl cellulose sodium q.d), positive control $(40 \mathrm{mg}(200 \mathrm{mg} / \mathrm{kgBW})$ catechin rutin sustained in the $2 \mathrm{~mL}$ of $0.5 \%$ carboxymethyl cellulose sodium q.d.), treatment $300 \mathrm{mg} / \mathrm{kgBW}$ (60 mg ethanol extract of Sunkist peel sustained in $2 \mathrm{~mL}$ of $0.5 \%$ carboxymethyl cellulose sodium q.d. human equivalent dosage (HED): $24.3 \mathrm{mg} /$ $\mathrm{kgBW}$ ), treatment $450 \mathrm{mg} / \mathrm{kg} \mathrm{BW}$ ( 90 mg ethanol extract of Sunkist peel sustained in $2 \mathrm{~mL}$ of $0.5 \%$ carboxymethyl cellulose sodium q.d. HED: 36.45 $\mathrm{mg} / \mathrm{kgBW})$, and treatment $600 \mathrm{mg} / \mathrm{kgBW}(120$ mg ethanol extract of Sunkist peels sustained in 
Table 1 AST Level Comparison in Treatment Groups

\begin{tabular}{lcccc}
\hline \multirow{2}{*}{ Group } & Mean (U/L)** & \multicolumn{2}{c}{ 95\% CI for Mean } & \multirow{2}{*}{ p-Value** } \\
\cline { 3 - 4 } & $334.27^{\mathrm{a}}$ & Lower Bound & Upper Bound & \\
\hline Negative & $49.70^{\mathrm{b}}$ & 31.20 & $1,301.07$ & \\
Positive & $168.73^{\mathrm{a}, \mathrm{c}}$ & 145.51 & 79.03 & $<0.01$ \\
Dosage $300 \mathrm{mg} / \mathrm{kgBW}$ & $118.22^{\mathrm{c}, \mathrm{d}}$ & 115.21 & 195.66 & \\
Dosage $450 \mathrm{mg} / \mathrm{kgBW}$ & $69.25^{\mathrm{b}, \mathrm{d}}$ & 50.58 & 121.34 & \\
Dosage $600 \mathrm{mg} / \mathrm{kgBW}$ & & 96.78 & \\
\hline
\end{tabular}

*The difference in small letter in the same column shows significance at p-value $<0.05$ with Post hoc test Tukey HSD. **p-value was obtained from one-way ANOVA against logarithmic value of AST level

$2 \mathrm{~mL}$ of $0.5 \%$ carboxymethyl cellulose sodium q.d. HED: $48.6 \mathrm{mg} / \mathrm{kgBW}$ ).

Each rat in treatment groups received 200 $\mathrm{mg}$ of paracetamol sustained in the $2 \mathrm{~mL}$ of $0.5 \%$ carboxymethyl cellulose sodium given 6 hours after receiving the last treatment on Day 14. The toxic effect of paracetamol occurs at a dose of $4 \mathrm{~g} /$ day in human, which was converted to 820 $\mathrm{mg} / \mathrm{kgBW}$ for rat. ${ }^{8,9}$ At the end of the treatment, the rats were sacrificed by injecting $50 \mathrm{mg} /$ kgBW intra-peritoneallyand blood sample was collected by cardiac puncture using $5 \mathrm{~mL}$ syringe and 25G-needle.

Dyasis reagent was prepared by mixing 4 parts of R1 and 1 part of R2 to form a monoreagent. The monoreagent was then added to $100 \mu \mathrm{L}$ of serum. The absorbance was read after a minute and repeated after 1, 2, and 3 minutes.

The ALT and AST levels were expressed as means and 95\% Confidence Interval for mean (upper and lower bound) of transform data (logarithmic). The Comparison of ALT and AST levels for each group were analyzed using oneway ANOVA, followed by Post hoc test Tukey HSD or Games Howell.

\section{Results}

The results for AST and ALT levels in treatment groups were assay among the group compared as described in the following table.

The above findings show that the AST level was significantly different between groups (p-value $<0.01)$. Furthermore, the post-hoc test showed that there was a significant difference between the highest and lowest dose of ethanol extract. The $300 \mathrm{mg} / \mathrm{kgBW}$ treatment group that received the lowest dose of extract was not significantly different from the negative group. A similar situation was seen in the group with the highest dose $(600 \mathrm{mg} / \mathrm{kgBW})$ which that did not show a significant difference with the positive group.

Based on the table above, the ALT level was significantly different between sample groups (p-value $<0.01)$. Furthermore, the post hoc test showed a significant difference between the negative and positive group. The group that received Sunkist ethanol extract at the lowest dose did not show any significant difference. This was similar to the group that received the highest dose of Sunkist ethanol extract and the positive group that did not show any significant difference between the two.

\section{Discussion}

The rats in this study were induced by paracetamol. Paracetamol is a drug that is

Table 2 ALT Level Comparison in Treatment Groups

\begin{tabular}{|c|c|c|c|c|}
\hline \multirow{2}{*}{ Group } & \multirow{2}{*}{$\operatorname{Mean}(\mathrm{U} / \mathrm{L})^{*}$} & \multicolumn{2}{|c|}{ 95\% CI for Mean } & \multirow{2}{*}{ p-value** } \\
\hline & & Lower Bound & Upper Bound & \\
\hline Negative & $438.73^{a}$ & 294.71 & 652.98 & \\
\hline Positive & $152.34^{\mathrm{b}}$ & 144.48 & 160.62 & \\
\hline Dosage $300 \mathrm{mg} / \mathrm{kgBW}$ & $316.01^{\mathrm{a}, \mathrm{c}}$ & 254.27 & 392.74 & $<0.01$ \\
\hline Dosage $450 \mathrm{mg} / \mathrm{kgBW}$ & $230.20^{b, c, d}$ & 170.49 & 310.89 & \\
\hline Dosage $600 \mathrm{mg} / \mathrm{kgBW}$ & $189.15^{\mathrm{d}}$ & 184.84 & 193.60 & \\
\hline
\end{tabular}

**The difference in small letter in the same column shows significance at p-value $<0.05$ with Post Hoc Test GamesHowell;**p-value was obtained from one-way ANOVA against logarithmic value of ALT level T 


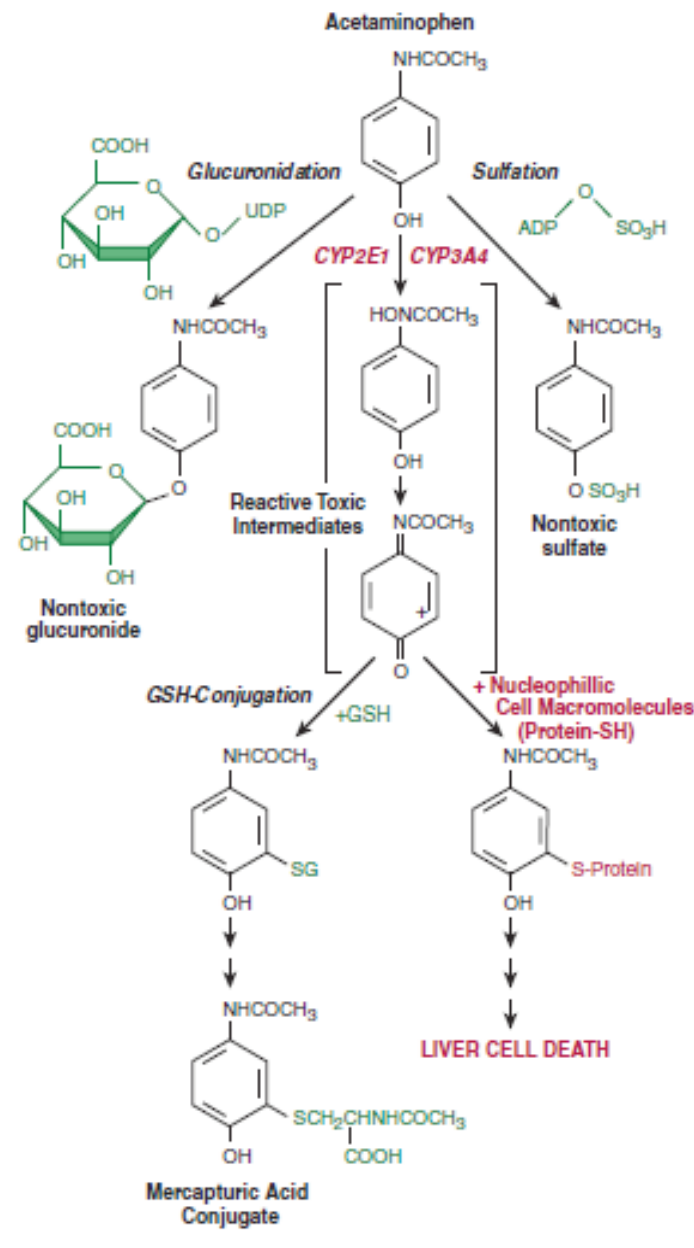

Figure Paracetamol Metabolism ${ }^{9}$

rapidly absorbed in the gastrointestinal tract and reaches the peak concentration within 90 minutes. It has a half-life between 2.0-2.5 hours which will prolong to more than 4 hours in hepatic injury patients. Around 95\% of paracetamol is conjugated by glucuronidation and sulfation pathway whereas the remaining $5 \%$ was conjugated by the biotransformation triggered by cytochrome P450 enzyme and isoenzyme CYP2EI. When the paracetamol is given in a therapeutic dose, the glucuronidation and sulfation pathway becomes saturated and the cytochrome P450 enzyme and isoenzyme CYP2EI pathway becomes the important pathway in the metabolism of paracetamol. However, paracetamol forms a reactive metabolite that has toxic properties and some free radicals through the biotransformation by cytochrome P450 enzyme and isoenzyme CYP2EI. Endogenous Glutathione is available for conjugation of the reactive metabolites. On the other hand, the GSH regeneration is not as fast as the production of the reactive metabolites due to the high intake of paracetamol, which leads to the higher amount of unconjugated reactive metabolites that exceeds the capacity of the GSH regeneration. These metabolites will disturb the membrane integrity of hepatocyte. leading to liver injury. Cytochrome P450 is widely distributed around the centrilobular region and liver injury will happen with the centrilobular region as the most common site. This injury increases the release of ALT and AST enzymes from the liver. The following figure depicts the metabolism of paracetamol. ${ }^{1,9,10}$

Evaluation of liver injury can be performed using some techniques, one of the them is by measuring biochemical serum indicators. These biochemical serum indicators include ALT and AST. The ALT, that stands for alanine amino transferase, is commonly found in some cytoplasmic cells in the kidney, heart, muscle, and liver as the catalyst of transamination reaction and is also found at a higher level in the liver than in other tissues. The normal range of this enzyme level is 7-56 U/L. Meanwhile, AST or aspartate amino transferase has two forms of isoenzyme that are commonly found in the mitochondrial form and cytoplasmic form. This enzyme is found at the highest level in the heart compared to other organs like the liver, skeletal muscle, and kidney. The normal range of AST level is 0 to $35 \mathrm{U} / \mathrm{L}$. An increase in ALT level indicates that there is a liver injury due to the high level of this enzyme in the liver. ${ }^{11,12}$

Therefore, reduced ALT and AST levels observed in the treatment group that receive the highest dose of Sunkist ethanol extract provide evidence of the protective effect of the Sunkist ethanol extract. This is due to the presence of phytochemicals that have antioxidants properties, including flavonoid and phenolic, that donate the hydroxyl group of phytochemical into the reactive metabolite of paracetamol, such as endogenous glutathione (GSH), to form Mercaptofuric acid conjugate that is more stable. Furthermore, it will reduce the formation of lipid peroxide in the blood rats. ${ }^{13-15}$

In conclusion, Sunkist ethanol extract has the potential for protecting the liver against paracetamol toxicity at a high dose $(600 \mathrm{mg} /$ $\mathrm{kgBW}$ ) with a similar protective effect as the catechine rutin as shown by the ALT and AST blood levels as the parameters. 


\section{References}

1. Hodgman MJ, Garrard AR. A Review of acetaminophen poisoning. Crit Care Clin. 2012;28(4):499-516. doi:10.1016/j.ccc. 2012.07.006

2. UB G, Tadvi NA. Paracetamol toxicity: a review. J Contemp Med Dent. 2014;2(3):125. doi:10.18049/jcmad/232

3. Jefferies S, Saxena M, Young P. Paracetamol in critical illness: A review. Crit Care Resusc. 2011;13(3):74-80.

4. Gunawan H. Pasar obat herbal capai rp 13 triliun. Tribun Bisnis. 2014. Available from: https://www.tribunnews.com/ bisnis/2014/06/10/pasar-obat-herbalcapai-rp-13-triliun.

5. Juniman PT. Jamu dan obat herbal masih diminati masyarakat. 2018. CNN Indonesia. Available from: https:// w w w. c n n ind o n e s i a.com/g a a hidup/20180417184633-255-291506/ jamu-dan-obat-herbal-masih-diminatimasyarakat.

6. Srivastava BD, Srivastava M, Srivastav SK, Suzuki N, Srivastav AK. Cypermethrininduced liver histopathology in rat: protective role of jamun seed and orange peel extracts. Iran J Toxicol. 2018;12(4):2530.

7. Setyawati I, Anggraeni R. Effectiveness of sweet orange peel extract (citrus sinensis) on the improvement of liver functions of animal trials induced by cigarette smoke. J Young Pharm. 2018;10(2):S132-5. doi:10.5530/ jyp.2018.2s.27

8. Nair A, Jacob S. A simple practice guide for dose conversion between animals and human. J Basic Clin Pharm. 2016;7(2):27. doi:10.4103/0976-0105.177703

9. Katzung BG, Masters SB, Trevor AJ. Basic \& Clinical Pharmacology. $12^{\text {th }}$ ed. New York: Mc Graw Hill Lange; 2012.

10. Alam J, Mujahid M, Badruddeen, Jahan Y, Bagga P, Rahman MA. Hepatoprotective potential of ethanolic extract of Aquilaria agallocha leaves against paracetamol induced hepatotoxicity in SD rats. J Tradit Complement Med. 2017;7(1):9-13. doi:10.1016/j.jtcme.2015.12.006

11. Gowda S, Desai PB, Hull V V, Math AAK, Vernekar SN, Kulkarni SS. A review on laboratory liver function tests. Pan Afr Med J. 2009;3:17.

12. Khosravi S, Alavian SM, Zare A, Daryani NE, Fereshtehnejad SM, Daryani NE, et al. Nonalcoholic fatty liver disease and correlation of serum alanin aminotransferase level with histopathologic findings. Hepat Mon. 2011;11(6):452-8.

13. Panche AN, Diwan AD, Chandra SR. Flavonoids: An overview. J Nutr Sci. 2016;5: e47. doi:10.1017/jns.2016.41

14. Sommella E, Pagano F, Pepe G, Ostacolo C, Manfra M, Chieppa M, et al. Flavonoid composition of tarocco (citrus sinensis 1 . Osbeck) clone 'lempso' and fast antioxidant activity screening by DPPH-UHPLC-PDA-ITTOF. Phytochem Anal. 2017;28(6):521-8.

15. Pepe G, Sommella E, Cianciarulo D, Ostacolo C, Manfra M, Sarno VD, et al. Polyphenolic extract from tarocco (Citrus sinensis l. osbeck) clone "lempso" exerts anti-inflammatory and antioxidant effects via NF-KB and Nrf-2 activation in murine macrophages. Nutrients. 2018;10(12):1961. doi:10.3390/nu10121961 